\title{
ОСОБЛИВОСТІ МІКРОЕЛЕМЕНТНОГО СКЛАДУ СКРОНЕВОЇ КІСТКИ ТА НИЖНЬОЇ ЩЕЛЕПИ ЗА УМОВ ДІАБЕТИЧНОЇ АРТРОПАТІЇ СКРОНЕВО-НИЖНЬОЩЕЛЕПНОГО СУГЛОБА
}

Вступ. Ушкодження суглобів у хворих на цукровий діабет є досить частим ускладненням. Особливості мікроелементного складу скроневої кістки та нижньої щелепи і структурні зміни скронево-нижньощелепного суглоба при цукровому діабеті вивчено недостатньо.

мета дослідження - вивчити особливості мікроелементного складу скроневої кістки та нижньої щелепи за умов діабетичної артропатії скронево-нижньощелепного суглоба.

Методи дослідження. За допомогою атомно-абсорбційного спектрального аналізу досліджено вміст мікроелементів (заліза, міді, цинку, магнію, марганцю, свинцю) у скроневій кістці та нижній щелепі 45 лабораторних статевозрілих білих щурів-самців, яких поділили на 3 групи: 1-ша група нараховувала 15 інтактних практично здорових тварин, 2-га - 15 щурів з місячною діабетичною артропатією променево-нижньощелепного суглоба, 3-тя - 15 тварин з двомісячною вказаною патологією. Зі скроневої кістки та нижньої щелепи виготовляли гістологічні мікропрепарати. Цукровий діабет моделювали шляхом одноразового внутрішньочеревного введення стрептозотоцину фрірми "Sigma" в дозі 50 мг/кг. Кількісні показники обробляли статистично.

Результати й обговорення. Встановлено, що при діабетичній артропатії скронево-нижньощелепного суглоба диспропорційно та нерівномірно зменшувався вміст заліза, міді, цинку, магнію, марганцю, свинцю у кістковій тканині скроневої кістки та нижньої щелепи. Вміст заліза у скроневій кістці при місячній діабетичній артропатії скронево-нижньощелепного суглоба знизився на 3,4 \%, а в нижній щелепі - на 4,8 \%, при двомісячній артропатії досліджувані показники змінилися, відповідно, на 4,8 та 13,7 \% (p<0,001). Вміст міді у скроневій кістці при місячній діабетичній артропатії зменшився на 3,4 \%, а в нижній щелепі на 3,8 \%, при двомісячному перебізі змодельованої патології - на 3,8 та 11,9 \% відповідно (p<0,001). Вміст цинку, магнію, марганцю, свинцю у скроневій кістці та нижній щелепі у досліджуваних експериментальних умовах знижувався аналогічно. Зміни вмісту досліджуваних мікроелементів залежали від тривалості діабетичної артропатії та домінували в нижній щелепі.

Висновки. Діабетична артропатія скронево-нижньощелепного суглоба призводить до нерівномірного та диспропорційного зменшення вмісту мікроелементів у скроневій кістці та нижній щелепі. Найбільш виражений дисбаланс між вмістом досліджуваних мікроелементів виявлено при двомісячній діабетичній артропатії скронево-нижньощелепного суглоба та в нижній щелепі.

КЛЮЧОВІ СЛОВА: скронево-нижньощелепний суглоб; діабетична артропатія; мікроелементи; скронева кістка; нижня щелепа.

ВСТУП. Ушкодження суглобів у хворих на цукровий діабет є досить частим ускладненням. Так, при цукровому діабеті 1 типу артропатію виявляють у 58 \% хворих, а при цукровому діабеті 2 типу - в 28 \% пацієнтів [1-3]. При вказаній патології порушується вуглеводний, білковий, мінеральний обмін, виникають гормональні розлади, ангіо- і нейропатії, що ускладнюється резорбцією кісткової тканини внаслідок дисбалансу остеокластної та остеобластної активності

(с). С. Гнатюк, Л. В. Рубас, Л. В. Татарчук, О. Б. Ясіновський, 2021.
[1-5]. Через високу глюкозотоксичність відбуваються накопичення кінцевих продуктів гліколізу, активація оксидативного стресу, а також розвиток низькорівневого запалення на організменому рівні. Ці фрактори зумовлюють аномальне ремоделювання суглобової, синовіальної, кісткової тканин та біохімічні зміни, що ускладнюються діабетасоційованою артропатією [6-8].

Скронево-нижньощелепний суглоб утворюють нижньощелепна ямка скроневої кістки, головка нижньої щелепи та внутрішньосуглобовий диск. Варто зазначити, що мікроелементний 
склад скроневої кістки та нижньої щелепи при діабетичній артропатії скронево-нижньощелепного суглоба залишається маловивченим. Водночас дослідження вмісту мікроелементів у кістковій тканині $€$ важливим для пояснення фрізіологічного та репаративного остеогенезу [1, 7, 8].

Мета дослідження - вивчити особливості мікроелементного складу скроневої кістки та нижньої щелепи за умов діабетичної артропатії скронево-нижньощелепного суглоба.

МЕТОДИ ДОСЛІДЖЕННЯ. За ДОПОМогоЮ атомно-абсорбційного спектрального аналізу [9-11] досліджено вміст мікроелементів у скроневій кістці та нижній щелепі 45 лабораторних статевозрілих білих щурів-самців, яких поділили на 3 групи: 1-ша група нараховувала 15 інтактних практично здорових тварин, 2-га - 15 щурів 3 місячною діабетичною артропатією скронево-нижньощелепного суглоба, 3-тя - 15 тварин з двомісячною вказаною патологією. Цукровий діабет моделювали шляхом одноразового внутрішньочеревного введення стрептозотоцину фрірми "Sigma" в дозі 50 мг/кг. Евтаназію тварин здійснювали через 1 і 2 місяці шляхом кровопускання за умов тіопенталового наркозу. Скроневу кістку та нижню щелепу очищували від м'яких тканин і за допомогою атомно-абсорбційного спектрального аналізу у вказаних кістках визначали вміст заліза (Fe), міді (Cu), цинку (Zn), магнію (Mg), марганцю (Mn) та свинцю $(\mathrm{Pb})$ [9-11]. Зі скроневої кістки та нижньої щелепи виготовляли також гістологічні мікропрепарати [12].

Отримані кількісні показники обробляли статистично. Обробку одержаних результатів виконано у відділі системних статистичних до- сліджень Тернопільського національного медичного університету імені І. Я. Горбачевського MO3 України у програмному пакеті STATISTICA (Stat.Soft. Inc, США). Різницю між порівнюваними показниками визначали за критеріями Стьюдента і Манна - Уїтні [13].

Варто вказати, що експериментальні дослідження та евтаназію щурів виконували з дотриманням Загальних етичних принципів експериментів на тваринах, ухвалених на Першому національному конгресі з біоетики (Київ, 2001), та відповідно до Європейської конвенції про захист хребетних тварин, що використовуються для дослідних та інших наукових цілей [14].

РЕЗУЛЬТАТИ Й ОБГОВОРЕННЯ. ОТРИМаНі в результаті проведеного дослідження дані наведено в таблиці. Під час усестороннього аналізу встановлено, що вміст досліджуваних мікроелементів у неушкоджених скроневій кістці та нижній щелепі був однаковим.

Виявлено також, що вже при місячній діабетичній артропатії вміст мікроелементів змінювався. Так, при місячній артропатії вміст заліза у скроневій кістці статистично достовірно ( $p<0,01)$ зменшився на 3,4 \%, а в нижній щелепі на 4,8 \%, при двомісячній артропатії досліджувані показники змінилися, відповідно, на 4,8 та 13,7 \% ( $p<0,001)$. Відомо, що залізо не $є$ структурним елементом кісткової тканини, проте відіграє важливу роль у процесах остеогенезу. Його десріцит у кістковій тканині може призводити до збільшення пористості кістки та погіршення ії біомеханічних властивостей [5].

Вміст міді у досліджуваних кістках також змінювався. При місячній змодельованій патології вміст вказаного мікроелемента у скроневій кістці зменшився на 3,4 \% (p<0,05), а в нижній

Таблиця - Вміст мікроелементів у скроневій кістці та нижній щелепі експериментальних тварин (M $\pm \mathrm{m})$

\begin{tabular}{|c|c|c|c|}
\hline \multirow{2}{*}{ Показник } & \multicolumn{3}{|c|}{ Г Група спостереження } \\
\hline & 1-ша & 2-га & 3-тя \\
\hline \multicolumn{4}{|c|}{ Скронева кістка } \\
\hline $\mathrm{Fe}, \mathrm{мкг/г}$ & $62,70 \pm 0,42$ & $60,56 \pm 0,45^{\star \star}$ & $57,56 \pm 0,45^{\star \star *}$ \\
\hline $\mathrm{Cu}, \mathrm{мкг/г}$ & $2,34 \pm 0,03$ & $2,26 \pm 0,03^{*}$ & $2,15 \pm 0,03^{\star \star}$ \\
\hline $\mathrm{Zn}, \mathrm{мг/ \Gamma}$ & $3,28 \pm 0,03$ & $3,15 \pm 0,02^{\star \star}$ & $2,80 \pm 0,02^{* \star *}$ \\
\hline Mg, мг/г & $1,90 \pm 0,02$ & $1,76 \pm 0,02^{\star \star}$ & $1,60 \pm 0,02^{\star \star \star}$ \\
\hline $\mathrm{Pb}, \mathrm{MКг/г}$ & $0,86 \pm 0,01$ & $0,81 \pm 0,01^{\star \star}$ & $0,72 \pm 0,01^{\star \star \star}$ \\
\hline \multicolumn{4}{|c|}{ Нижня щелепа } \\
\hline $\mathrm{Fe}$, мкг/г & $62,66 \pm 0,45$ & $59,65 \pm 0,42^{\star \star}$ & $54,10 \pm 0,42^{\star \star \star}$ \\
\hline $\mathrm{Cu}, \mathrm{мкг/г}$ & $2,36 \pm 0,03$ & $2,27 \pm 0,03^{*}$ & $2,08 \pm 0,02^{\star \star \star}$ \\
\hline $\mathrm{Zn}, \mathrm{мг/ \Gamma}$ & $3,30 \pm 0,03$ & $3,12 \pm 0,03^{\star \star}$ & $2,80 \pm 0,02^{* \star *}$ \\
\hline
\end{tabular}

Примітка. * - p<0,05; ** - p<0,01; *** - p<0,001 порівняно з 1-ю групою. 
щелепі - на 3,8 \%, при двомісячному ушкодженні скронево-нижньощелепного суглоба за умов цукрового діабету досліджувані показники знизилися, відповідно, на 3,8 та 11,9% (p<0,001).

Відомо, що мідь у фрізіології кісткової тканини виконує фрункцію каталізатора ряду ензимних систем в остеогенних клітинах і сприяє підтриманню рівня їх дифреренціації. Деякі дослідники вказують на важливу роль міді в енергетичному транспортному механізмі між апатитом і колагеном. Варто вказати, що найбільший вміст цього мікроелемента виявляють у молодих остеонах. Мідь бере також участь у процесах синтезу колагену й еластину та перешкоджає процесам демінералізації кісткової тканини $[10,11]$.

Під час досліджень виявлено зменшення за умов діабетичної артропатії скронево-нижньощелепного суглоба вмісту цинку в скроневій кістці та нижній щелепі. Так, при місячній діабетичній артропатії вміст цього мікроелемента у скроневій кістці статистично достовірно $(p<0,01)$ знизився $3(3,28 \pm 0,03)$ до $(3,15 \pm 0,02) \mathrm{мг/} /$ тобто майже на 4,0 \%, при двомісячній - на $14,6$ \% ( $p<0,001)$. У нижній щелепі за змодельованих експериментальних умов вміст цинку зменшився, відповідно, на 5,4 (p<0,01) та 15,1 \% $(p<0,001)$. Відомо, що цинк $є$ найпоширенішим в організмі людини мікроелементом і відіграє важливу роль у стимулюванні росту, фрормуванні та регенерації кісткової тканини і зниження його вмісту в кістках негативно впливає на вказані процеси $[10,11]$.

Магній - один із поширених у людському організмі мікроелементів. Відомо, що третина магнію локалізована в кістках і виконує функцію депо. При місячній діабетичній артропатії скронево-нижньощелепного суглоба його вміст у скроневій кістці статистично достовірно $(\mathrm{p}<0,01)$ зменшився на 7,4 \%, при двомісячній вказаній патології - на 15,8 \% (p<0,001). Зниження кількості магнію призводить до гіпокальціємії, сповільнення росту кісток, прискорення процесів резорбції, зменшення маси кісток, остеопорозу [4]. У нижній щелепі при змодельованому патологічному процесі вміст цього мікроелемента зменшився, відповідно, на 9,9 та 21,8\% $(p<0,001)$.

Аналогічно змінювалася кількість марганцю у досліджуваних кістках при діабетичній артропатії скронево-нижньощелепного суглоба. При місячній змодельованій патології його вміст у скроневій кістці знизився на 8,2 \% (p<0,01), при двомісячному перебізі діабетичної артропатії на 14,4 \% ( $p<0,001)$. Вміст досліджуваного хімічного середника в нижній щелепі при змодельованій патології зменшився, відповідно, на 9,3\% $(p<0,01)$ та 14,4\% $(p<0,001)$. Відомо, що марганець при зниженні його вмісту в кістках гальмує процеси осифікації, зменшує мінералізацію колагенових фрібрил та порушує синтез глікозаміногліканів. Останні відіграють важливу роль у фрормуванні кісткової та хрящової тканин $[4,10,15]$.

Під час досліджень встановлено, що найменше в неушкоджених скроневій кістці та нижній щелепі було свинцю порівняно 3 іншими мікроелементами. При діабетичній артропатії скронево-нижньощелепного суглоба його вміст у вказаних кістках знижувався. Так, при місячній діабетичній артропатії вміст свинцю у скроневій кістці зменшився на 5,8 \% $(p<0,01)$, при двомісячній - на 16,3 \% ( $<<0,001)$, а в нижній щелепі - на 8,1 та 20,9 \% відповідно ( $<<0,001)$. Свинець належить до токсичних елементів, і збільшення його вмісту може негативно впливати на регенеративні процеси в кістках [10].

Гістологічно відмічали дегенеративні процеси у хрящах нижньощелепної ямки скроневої кістки та головки нижньої щелепи. У досліджуваних кістках (скронева кістка, нижня щелепа) спостерігали порожнини резорбції, мозаїчно забарвлені ділянки з вираженим деструктивним процесом. Мали місце зменшення кількості остеобластів, зони патологічного кісткоутворення, які характеризувалися збільшенням кількості атипових кісткових балок з порушеною структурою, що визначали за розростанням клітинно-волокнистої тканини в міжбалкових просторах. Виявлені морфрологічні зміни домінували в нижній щелепі. Вищенаведені дані, а також більш виражений дисбаланс між вмістом мікроелементів у вказаній кістці при змодельованій артропатії можна пояснити більшим навантаженням, яке припадає на неушкоджену нижню щелепу, а також патологічними станами.

Встановлено, що діабетична артропатія скронево-нижньощелепного суглоба суттєво змінює вміст мікроелементів у скроневій кістці та нижній щелепі. Варто зазначити, що у досліджуваних кістках він знижується нерівномірно та диспропорційно, суттєво порушуючи баланс між ними. Найбільш виражено вміст досліджуваних мікроелементів у скроневій кістці та нижній щелепі знижувався при двомісячній діабетичній артропатії скронево-нижньощелепного суглоба. Необхідно зазначити, що зміни вмісту заліза, міді, цинку, магнію, марганцю, свинцю в нижній щелепі виявилися більш вираженими порівняно зі скроневою кісткою.

ВИСНОВКИ. Діабетична артропатія скронево-нижньощелепного суглоба призводить до нерівномірного та диспропорційного зменшення вмісту мікроелементів у скроневій кістці та ниж- 
ній щелепі. Найбільш виражений дисбаланс між вмістом досліджуваних мікроелементів виявлено при двомісячній діабетичній артропатії скронево-нижньощелепного суглоба та в нижній щелепі.

\section{СПИСОК ЛІТЕРАТУРИ}

1. Орленко В. Л. Гормональні характеристики діабет-асоційованих остеоартритів / В. Л. Орленко // Вісн. проблем біології та медицини. - 2020. Вип. 2 (159). - С. 138-143.

2. Musculoskeletal complications in type 1 diabetes / M. Larkin, A. Barnie, B. Braffett, P. Cleary // Diabetes Care. - 2014. - 37 (7). - P. 1863-1869.

3. Кризина О. В. Трофрічні порушення тканин нижніх кінцівок при цукровому діабеті 2 типу / О. В. Кризина // Клініч. ендокринологія та ендокринна хірургія. 2018. - № 1 (6). - С. 15-24.

4. Лукьянцева Г. В. Особенности химического состава костей белых крыс после двухмесячного употребления натрия бензола и возможности его коррекции / Г. В. Лукьянцева // Укр. морфол. альм. 2014. - 12, № 4. - C. 61-66.

5. Role of hormones in cartiage and joint metabolism: understanding an unhealthy metabolic phenotype in osteoarthritis / A. Bay-Jensen, E. Slagboom, P. ChenAn, P. Alexandersen // Menopause. - 2013. - 20 (5). P. 578-586.

6. Insulin decreases autophagy and leads to cartilage degradation / M. Ribeiro, P. Lopez de Figueroa, F. Bianco, A. Mendes // Osteoarthritis. Cartilage. - 2016. 24 (4). - P.731-739.

7. Berenbaum F. Diabetes induced osteoarthritis from a new paradigm to a new phenotype / F. Berenbaum // Ann. Rheum. Dis. - 2011. - 70 (8). - P. 1354 -1356.

\section{REFERENCES}

1. Orlenko, L. (2020). Hormonalni kharakterystyky diabet-asotsiiovanykh osteoartrytiv [Hormonal characteristics of diabetes-associated osteoarthritis]. Visnyk problem biolohii ta medytsyny - Bulletin of Problems Biology and Medicine, 2 (159), 138-143 [in Ukrainian].

2. Larkin, M., Barnie, A., Braffett, B., Cleary, P., \& Diminick, L. (2014). Musculoskeletal complications in type 1 diabetes. Diabetes Care, 37 (7), 1863-1869.

3. Kryzyna, O.V. (2018). Trofichni porushennia tkanyn nyzhnikh kintsivok pry tsukrovomu diabeti 2 typu [Trophic disorders of the tissues of the lower extremities in type 2 diabetes]. Klinichna endokrynolohiia ta endokrynna khirurhiia - Clinical Endocrinology and Endocrine Surgery, 1 (6), 15-24 [in Ukrainian].

4. Lukyantseva, G.V. (2014). Osobennosti khimicheskogo sostava kostey belykh krys posle dvukhmesyachnogo upotrebleniya natriya benzola i vozmozhnosti yego korrektsii [Features of the chemical composi-
Перспективи подальших досліджень. Всестороннє вивчення вмісту мікроелементів у кістковій тканині при діабетичних артропатіях дозволить при цьому суттєво покращити діагностику, корекцію та профрілактику уражень кісток.

8. Tu M. The pathogenic role connective tissue growth factor in ostheoarthritis / M. Tu, F. Qiao, L. Wong // Biosci. Rep. - 2019. - 39 (7). - P. 1374-1376.

9. Брицке Э. М. Атомно-абсорбционный спектральный анализ / Э. М. Брицке. - М. : Химия, 1982. $244 \mathrm{c}$.

10. Мікроелементний склад довгих та мішаних кісток скелета в нормі / Є. В. Гусак, М.В.Погорелов, Г. Ф. Ткач, С. М. Данильченко // Укр. морфол. альм. 2010. - 8, № 4. - С. 51-55.

11. Зміни хімічного складу кісток щурів під впливом жовтого барвника тартразину / Г. В. Лук'янцева, В. А. Пастухова, О. Г. Ковальчук, У. М. Дутчак // Світ медицини та біології. - 2019. - № 4 (70). - С. 203-208.

12. Горальський Л. П. Основи гістологічної техніки і морфофрункціональні методи дослідження в нормі і при патології / Л. П. Горальський, В.П. Хомич, О. І. Конопський. - Житомир : Полісся, 2011. - 288 с.

13. Гжибовский А. И. Сравнение количественных данных двух парных выборок с использованием программного обеспечения Statistika i SPSS: параметрические и непараметрические критерии / А. И. Гжибовский, О. И. Иванов, М. А. Горбатова // Наука и здравоохранение. - 2016. - № 3. - С. 5-25.

14. Резніков О. Г. Загальні етичні принципи експериментів на тваринах / О. Г. Резніков // Ендокринологія. - 2003. - № 8 (1). - С. 142-145.

15. Hordon L. Limited joint mobility and other musculoskeletal problems in diabetes / L. Hordon // Diabetes Primary Care. - 2017. - 19. - P. 29-34.

tion of the bones of white rats after two months of use of benzene sodium and the possibility of its correction]. Ukrainskyi morfolohichnyi almanakh - Ukrainian Morphological Almanac, 12 (4), 61-66 [in Ukrainian].

5. Bay-Jensen, A., Slagboom, E., Chen-An P., \& Alexandersen, P. (2013). Role of hormones in cartiage and joint metabolism: understanding an unhealthy metabolic phenotype in osteoarthritis. Menopause, 20 (5, 578-586.

6. Ribeiro, M., Lopez de Figueroa, P., Bianco, F., \& Mendes, A. (2016). Insulin decreases autophagy and leads to cartilage degradation. Osteoarthritis. Cartilage, 24 (4), 731-739.

7. Berenbaum, F. (2011). Diabetes induced osteoarthritis from a new paradigm to a new phenotype. Ann. Rheum. Dis., 70 (8), 1354-1356.

8. Tu, M., Qiao, F., \& Wong, L. (2019) The pathogenic role connective tissue growth factor in ostheoarthritis. Biosci. Rep., 39 (7), 1374-1376. 
9. Britske, E.M. (1982). Atomno-absorbtsionnyy spektralnyy analiz [Atomic absorption spectral analysis]. Moscow: Khimiya [in Russian].

10. Husak, Ye.V., Pohorelov, M.V., Tkach, H.F., \& Danylchenko, S.M. (2010). Mikroelementnyi sklad dovhykh ta mishanykh kistok skeleta v normi [Microelement composition of long and mixed skeletal bones in norm]. Ukrainskyi morfolohichnyi almanakh - Ukrainian Morphological Almanac, 8 (4), 51-55 [in Ukrainian].

11. Lukyantseva, H.V., Pastukhova, V.A., Kovalchuk, O.H., \& Dutchak, U.M. (2019). Zminy khimichnoho skladu kistok shchuriv pid vplyvom zhovtoho barvnyka tartrazynu [Changes in the chemical composition of rat bones under the influence of the yellow dye tartrazine]. Svit medytsyny ta biolohii - The World of Medicine and Biology, 4 (70), 203-208 [in Ukrainian].

12. Horalskyy, L.P., Khomych, V.P., \& Konopskyy, O.I. (2011). Osnovy histolohichnoi tekhniky imorfofunktsionalni metody doslidzhennia v normi i pry patolohii [Fundamentals of histological technique and morphofunctional research methods in normal and in pathology]. Zhytomyr: Polissia [in Ukrainian].

13. Gzhibovskiy, A.I., Ivanov, O.I., \& Gorbatova, M.A. (2016). Sravneniye kolichestvennykh dannykh dvukh parnykh vyborok s ispolzovaniyem programmnogo obespecheniya Statistika i SPSS: parametricheskiye i neparametricheskiye kriterii [Comparison of quantitative data of two paired samples using Statistika i SPSS software: parametric and nonparametric criteria]. Nauka i zdravookhraneniye - Science and Healthcare, 3, 5-25 [in Ukrainian].

14. Reznikov, O.H. (2003). Zahalni etychni pryntsypy eksperymentiv na tvarynakh [General ethical principles of animal experiments]. Endokrynolohiia-Endocrinology, 8 (1), 142-145 [in Ukrainian].

15. Hordon, L. (2017). Limited joint mobility and other musculoskeletal problems in diabetes. Diabetes Primary Care, 19, 29-34.

\section{ОСОБЕННОСТИ МИКРОЭЛЕМЕНТНОГО СОСТАВА ВИСОЧНОЙ КОСТИ И НИЖНЕЙ ЧЕЛЮСТИ В УСЛОВИЯХ ДИАБЕТИЧЕСКОЙ АРТРОПАТИИ ВИСОЧНО-НИЖНЕЧЕЛЮСТНОГО СУСТАВА}

\section{Резюме}

Вступление. Повреждение суставов у больных сахарным диабетом является достаточно частым осложнением. Особенности микроэлементного состава височной кости и нижней челюсти и структурные изменения височно-нижнечелюстного сустава при сахарном диабете изучены недостаточно.

Цель исследования - изучить особенности микроэлементного состава височной кости и нижней челюсти в условиях диабетической артропатии височно-нижнечелюстного сустава.

Методы исследования. С помощью атомно-абсорбционного спектрального анализа исследовано содержание микроэлементов (железа, меди, цинка, магния, марганца, свинца) в височной кости и нижней челюсти 45 лабораторных половозрелых белых крыс-самцов, которых разделили на 3 группы: 1-я группа насчитывала 15 интактных практически здоровых животных, 2-я - 15 крыс с месячной диабетической артропатией височно-нижнечелюстного сустава, 3-я - 15 животных с двухмесячной указанной патологией. Из височной кости и нижней челюсти изготавливали гистологические микропрепараты. Сахарный диабет моделировали путем однократного внутрибрюшного введения стрептозотоцина фрирмы “Sigma” в дозе 50 мг/кг. Количественные показатели обрабатывали статистически.

Результаты и обсуждение. Установлено, что при диабетической артропатии височно-нижнечелюстного сустава диспропорционально и неравномерно уменьшалось содержание железа, меди, цинка, магния, марганца, свинца в костной ткани височной кости и нижней челюсти. Содержание железа в височной кости при месячной диабетической артропатии височно-нижнечелюстного сустава снизилось на 3,4 \%, а в нижней челюсти - на 4,8 \%, при двухмесячной артропатии исследуемые показатели изменились, соответственно, на 4,8 и 13,7 \% (p<0,001). Содержание меди в височной кости при месячной диабетической артропатии уменьшилось на 3,4 \%, а в нижней челюсти - на 3,8 \%, при двухмесячном течении смоделированной патологии - на 3,8 и 11,9 \% соответственно (p<0,001). Содержание цинка, магния, марганца, свинца в височной кости и нижней челюсти в исследуемых экспериментальных условиях снижалось аналогично. Изменения содержания исследуемых микроэлементов зависели от длительности диабетической артропатии и доминировали в нижней челюсти.

Выводы. Диабетическая артропатия височно-нижнечелюстного сустава приводит к неравномерному и диспропорциональному уменьшению содержания микроэлементов в височной кости и нижней че- 
люсти. Наиболее выраженный дисбаланс между содержанием исследуемых микроэлементов обнаружен при двухмесячной диабетической артропатии височно-нижнечелюстного сустава и в нижней челюсти.

КЛЮЧЕВЫЕ СЛОВА: височно-нижнечелюстной сустав; диабетическая артропатия; микроэлементы; височная кость; нижняя челюсть.

M. S. Hnatjuk, L. V. Rubas, L. V. Tatarchuk, O. B. Jasinovsky I. HORBACHEVSKY TERNOPIL NATIONAL MEDICAL UNIVERSITY

\section{PECULIARITIES OF MICROELEMENT COMPOSITION OF TEMPORAL BONE AND LOWER JAW IN THE CONDITIONS OF DIABETIC ARTHROPATHY OF TEMPOROMANDIBULAR JOINT}

\section{Summary}

Introduction. Joint damage in patients with diabetes is a fairly common complication. Peculiarities of the microelement composition of the temporal bone and mandible and structural changes of the temporomandibular joint in diabetes have been insufficiently studied.

The aim of the study - to learn the features of the microelement composition of the temporal bone and mandible in diabetic arthropathy of the temporomandibular joint.

Research Methods. Atomic absorption spectral analysis examined the content of trace elements (iron, cuprum, zinc, magnesium, manganese, lead) in the temporal bone of the mandible of 45 laboratory mature white male rats, which were divided into 3 groups. Group 1 consisted of 15 intact practically healthy animals, group $2-15$ rats with monthly diabetic arthropathy of the temporomandibular joint, group 3-15 animals with two-month specified pathology. Histological micropreparations were also made from the temporal bone and mandible. Diabetes mellitus was simulated by a single intraperitoneal injection of streptozotocin by Sigma at a dose of $50 \mathrm{mg} / \mathrm{kg}$. Quantitative indicators were processed statistically.

Results and Discussion. It was established that in diabetic arthropathy of the temporomandibular joint the content of iron, cuprum, zinc, magnesium, manganese, lead in the bone tissue of the temporal bone and mandible decreases disproportionately and unevenly. It was found that the iron content in the temporal bone in monthly diabetic arthropathy decreased by $3.4 \%$, and in the lower jaw - by $4.8 \%$, in two-month arthropathy, the studied indicators changed by $4.8 \%$ and $13.7 \%$, respectively $(p<0.001)$. The cuprum content in temporal diabetic arthropathy of the temporomandibular joint in the temporal bone decreased by $3.4 \%$, in the lower jaw - by $3.8 \%$, with a two-month course of simulated pathology - by $3.8 \%$ and $11.9 \%$, respectively $(p<0.001)$. The content of zinc, magnesium, manganese, lead in the temporal bone and mandible in the studied experimental conditions decreased similarly. Changes in the content of the studied microelements depend on the duration of diabetic arthropathy and dominate in the lower jaw.

Conclusions. Diabetic arthropathy of the temporomandibular joint leads to an uneven, disproportionate decrease in the content of microelements in the temporal bone and lower jaw. The most pronounced imbalance between the content of the studied microelements was found in two-month diabetic arthropathy of the temporomandibular joint and in the lower jaw.

KEY WORDS: temporomandibular joint; diabetic arthropathy; microelements; temporal bone; lower jaw.

Отримано 26.02.21

Адреса для листування: М. С. Гнатюк, Тернопільський національний медичний університет імені І. Я. Горбачевського МОз України, майдан Волі, 1, Тернопіль, 46001, Україна, e-mail: hnatjuk@tdmu.edu.ua. 